\title{
Diversity of Lecidea (Lecideaceae, Ascomycota) species revealed by molecular data and morphological characters
}

\author{
ULRIKE RUPRECHT ${ }^{1}$, H. THORSTEN LUMBSCH ${ }^{2}$, GEORG BRUNAUER ${ }^{1}$, T.G. ALLAN GREEN ${ }^{3,4}$ and \\ ROMAN TÜRK ${ }^{1}$ \\ ${ }^{I}$ Department of Organismic Biology, University of Salzburg, Hellbrunnerstr. 34, 5020 Salzburg, Austria \\ ${ }^{2}$ Department of Botany, The Field Museum, 1400 S, Lake Shore Drive, Chicago, IL 60605, USA \\ ${ }^{3}$ Biological Sciences, Waikato University, Hamilton, New Zealand \\ ${ }^{4}$ Vegetal II, Farmacia Facultad, Universidad Complutense, Madrid, Spain \\ ulrike.ruprecht@sbg.ac.at
}

\begin{abstract}
The diversity of lichens, especially crustose species, in continental Antarctica is still poorly known. To overcome difficulties with the morphology based species delimitations in these groups, we employed molecular data (nuclear ITS and mitochondrial SSU rDNA sequences) to test species boundaries within the genus Lecidea. Sampling was done along a north-south transect at five different areas in the Ross Sea region (Cape Hallett, Botany Bay to Mount Suess, Taylor Valley, Darwin Area and Mount Kyffin). A total of 153 specimens were collected from 13 localities. Phylogenetic analyses also include specimens from other regions in Antarctica and non-Antarctic areas. Maximum parsimony, maximum likelihood and Bayesian analyses agreed in placing the samples from continental Antarctica into four major groups. Based on this phylogenetic estimate, we restudied the micromorphology and secondary chemistry of these four clades to evaluate the use of these characters as phylogenetic discriminators. These clades are identified as the following species Lecidea cancriformis, $L$. andersonii as well as the new species L. polypycnidophora Ruprecht \& Türk sp. nov. and another previously unnamed clade of uncertain status, referred to as Lecidea sp. (L. UCR1).
\end{abstract}

Received 16 October 2009, accepted 13 April 2010

Key words: chemical races, lichens, phylogenetic analysis, secondary metabolites

\section{Introduction}

The diversity of lichens in Antarctica is poorly known. This is especially true for crustose lichens that are often reduced to minute patches surrounding ascomata under the harsh climatic conditions typical of this ecosystem. The number of available collections is limited, which restricts the ability to assess variability within species. Lecideoid lichens are abundant and rich in species in Antarctica (Hertel 2007) and, because of the poor understanding of morphological and chemical variation, their taxonomy is currently in urgent need of revision. Most of the lecideoid taxa are confined to the sub-Antarctic and maritime Antarctic regions with only a few species known to occur in the more extreme environmental conditions of continental Antarctica. Lecideoid lichens often act as pioneers on rock and pebbles (Hertel 1987). At the more southern and very dry parts of continental Antarctica lecideoid lichens are among the few occurring lichen groups (Stevens et al. unpublished, Marshall et al. unpublished).

Saxicolous lecideoid lichens in Antarctica include species of the genera Carbonea, Lecanora, Lecidea, and Lecidella. Despite the ecological importance of these lichens in polar habitats, the taxonomy is only poorly known and the circumscription of taxa differs between authors. Only a few lecideoid lichens are recorded from continental Antarctica (Pickard \& Seppelt 1984, Hale 1987,
Hertel 1987, 1988, Jacobsen \& Kappen 1988, Seppelt et al. 1988, 1995, Andreev 1990, Kappen et al. 1990, Inoue 1991, 1995, Melick et al. 1994, Upreti 1996, Broady \& Weinstein 1998, Øvstedal \& Lewis Smith 2001, Castello 2003).

The diversity of species in Antarctic lichens has been a matter of debate for a long time. While some authors claimed about $97 \%$ of the Antarctic lichen species to be endemic (Dodge 1973), others considered c. 20\% as being more realistic (Hertel 1988, Seppelt et al. 1998). In most recent studies, many of the previously described endemic species, have been reinterpreted as variations due to extreme climatic conditions. One prominent example is the Antarctic endemic Lecidea cancriformis (Hertel 2007). Different morphotypes of this lichen have been interpreted as different species but recent morphological studies have suggested that they should be synonymised with L. cancriformis (Castello 2003). These morphology-based studies (Castello 2003, Hertel 2007) accept two Lecidea species ( $L$. andersonii, $L$. cancriformis) in continental Antarctica. However, molecular data are largely absent for Antarctic lichens, with only a few exceptions (Dyer \& Murtagh 2001, Ohmura \& Kanda 2004, Ott et al. 2004, Seymour et al. 2007, Wirtz et al. 2006, 2008, Lee et al. 2008). The evaluation of morphological characters and identification of crustose lecideoid lichens is hampered in polar regions, due to common occurrence of chasmolithic 
Table I. Investigation sites with the number of the collected Lecidea specimens and the total number of collected specimens from Ross Sea Region. The dates of the expeditions at the Ross Sea Region are in parenthesis. Specimens for collection sites 6-9 were provided as herbarium vouchers from R. Seppelt and M. Andreev for a broader taxon sampling across the entire continental Antarctica.

\begin{tabular}{llrr}
\hline Collection sites & $\begin{array}{c}\text { Lecidea } \\
\text { specimens }\end{array}$ & $\begin{array}{c}\text { Total number of } \\
\text { specimens collected }\end{array}$ \\
\hline 1. & Cape Hallett (2004) & 1 & 20 \\
2. Botany Bay-Granite Harbour-Discovery Bluff & 28 & 70 \\
b. Mount Suess-Sperm Bluff (2000, 2008) & 5 & 14 \\
3. Taylor Valley 2003 & 11 & 21 \\
4. Darwin Area: a. Brown Hills (2004) & b. Lake Wellman (2007) & 46 & 67 \\
& c. Diamond Hill - Bartrum Basin (2009) & 7 & 18 \\
5. Mount Kyffin (2003) & 53 & 58 \\
6. Wilkes Land (R. Seppelt) & 2 & - \\
7. Mac. Robertson Land (M. Andreev) & 10 & \\
8. Princess Elizabeth Land (M. Andreev) & 2 & \\
9. Dronning Maud Land (M. Andreev) & 2 & - \\
\hline
\end{tabular}

growth and ascomata lacking ascospores or with only sparsely developed ascospores (Hertel 2009).

To overcome difficulties of assessing species diversity in Antarctic lecideoid lichens, we employed molecular data (nuclear ITS and mitochondrial SSU ribosomal DNA sequences) to test species boundaries. We used a phylogenetic species concept based on a two-gene dataset in this study to circumscribe species in these lichens (Grube \& Kroken 2000). Based on our phylogenetic estimate we re-evaluated morphological and chemical characters to identify characters that can be used to identify these distinct lineages. Here we have focused on samples belonging to the genus Lecidea s. str. Collections were made from five different regions in continental Antarctica along a north-south coastal transect within the Ross Sea region $\left(72-84^{\circ} \mathrm{S}\right) .153$ specimens of the genus Lecidea were found in all habitats (Tables I \& II, Figs $1 \&$ 2). To complete the sampling we included samples from other regions of continental Antarctica (Tables I \& II, Fig. 1), Arctic regions (Svalbard/Norway, Greenland), Austria, Sweden and the USA (Table II).

\section{Material and methods}

\section{Investigation sites}

The collection sites are located on the western coast of the Ross Sea (Table I, Figs $1 \&$ 2). The Transantarctic Mountains are to the west and strongly affect the local climate. In particular, föhn-like winds contribute to the unusual dryness of the whole of southern Victoria Land and the McMurdo Dry Valleys in particular (Green et al. 1992). The saxicolous vegetation is extremely sparse. Lichens are only found where special microclimatic conditions occur and where they benefit from protection from abrasion of wind blown particles, from meltwater from melting snow and ice and by increased warmth (Green et al. 2007).

1. Cape Hallett, northern Victoria Land $\left(72^{\circ} 19^{\prime} \mathrm{S}\right.$, $\left.170^{\circ} 16^{\prime} \mathrm{E}\right), 0-300 \mathrm{~m}$ alt., January 2004
The area is a low lying gravel spit with a steep slope to the south rising from sea level to about $300 \mathrm{~m}$ alt.; the scree on the slope protects the vegetation from the strong winds. The area is ice free during the late spring and summer, the melting water forms numerous small channels through the flatter vegetated areas and precipitation is low (Pannewitz et al. 2005). The level area is composed of beach gravels and cliff talus and a high nutrient input is guaranteed by a rich birdlife in the area (Green et al. 2000).

2. a. Granite Harbour-Botany Bay-Discovery Bluff, Victoria Land, Ross Dependency $\left(77^{\circ} 00^{\prime} \mathrm{S}, 162^{\circ} 27^{\prime}-\right.$ $\left.163^{\circ} 35^{\prime} \mathrm{E}\right), 0-435 \mathrm{~m}$ alt., January 2000, 2008

During the summer season the area is snow free and protected from high winds. Several small streamlets of melting water flow from the snowfields of the adjacent ridges (Pannewitz et al. 2005) and the area has an exceptional moss and lichen vegetation (Taylor 1913).

b. Mount Suess $\left(77^{\circ} 02^{\prime} \mathrm{S}, 161^{\circ} 34^{\prime}-161^{\circ} 43^{\prime} \mathrm{E}\right), 730-755 \mathrm{~m}$ alt. Sperm Bluff $\left(77^{\circ} 03^{\prime}-77^{\circ} 05^{\prime} \mathrm{S}, 161^{\circ} 43^{\prime} \mathrm{E}\right) 522 \mathrm{~m}$ alt., 2008

These two inland mountains are within a glacial ice sheet (south of Mackay Glacier). The region is snow free in summer and a well sheltered area with a pond at the bottom is located below the top of Mount Suess. Mount Suess consists of a complex of granodiorite, gneiss, dolerite and sandstone (Gunn \& Warren 1962). Sperm Bluff is composed of big granite boulders, ephemeral streams appear not to be present.

3. Taylor Valley, Victoria Land $\left(77^{\circ} 34^{\prime}-77^{\circ} 41^{\prime} \mathrm{S}, 162^{\circ} 15^{\prime}-\right.$ $\left.163^{\circ} 05^{\prime} \mathrm{E}\right), 0-1143 \mathrm{~m}$ alt., January 2003

The collecting sites are located close to the Canada Glacier ( $40 \mathrm{~m}$ alt.), Mount Falconer north from Lake Fryxell (718 m alt.) and Aasgard Range at the Rhone Glacier (1143 m alt.). Taylor Valley is a classic dry valley and is a part of the McMurdo Dry Valleys, which 
Table II. Specimen information - location, collector, date, herbarium number and Genbank-accession numbers of mtSSU, ITS.

\begin{tabular}{|c|c|c|c|c|c|}
\hline No. & Name of species & Sample & Herbarium & ITS & $\mathrm{mtSSU}$ \\
\hline 1 & $\begin{array}{l}\text { Farnoldia jurana ssp. jurana } \\
\text { (Schaer.) Hertel }\end{array}$ & $\begin{array}{l}\text { AUSTRIA, Salzburg: Pongau } \\
22 \text { Jul 06, leg: R. Türk \& U. Ruprecht }\end{array}$ & R. Türk 39660 & EU263920 & GU074511 \\
\hline 2 & Lecidea andersonii Filson & $\begin{array}{l}\text { ANTARCTICA, Dronning Maud Land: Schirmacher Oasis } \\
20 \text { Mar 03, leg \& det: M. Andreev }\end{array}$ & LE A0515601 & GU074445 & GU074469 \\
\hline 3 & L. andersonii & $\begin{array}{l}\text { ANTARCTICA, Dronning Maud Land: Schirmacher Oasis } \\
21 \text { Mar 03, leg \& det: M. Andreev }\end{array}$ & LE A0515901 & GU074446 & GU074470 \\
\hline 4 & L. andersonii & $\begin{array}{l}\text { ANTARCTICA, Victoria Land: Botany Bay } \\
16 \text { Jan } 08 \text {, leg \& det: U. Ruprecht }\end{array}$ & R.Türk 43008 & GU074450 & GU074463 \\
\hline 5 & L. andersonii & $\begin{array}{l}\text { ANTARCTICA, Victoria Land: Botany Bay } \\
16 \text { Jan } 08 \text {, leg \& det: U. Ruprecht }\end{array}$ & R.Türk 43011 & GU074452 & GU074464 \\
\hline 6 & L. andersonii & $\begin{array}{l}\text { ANTARCTICA, Victoria Land: Granite Harbour } \\
15 \text { Jan } 08 \text {, leg \& det: U. Ruprecht }\end{array}$ & R. Türk 43006 & GU074453 & GU074462 \\
\hline 7 & L. andersonii & $\begin{array}{l}\text { ANTARCTICA, Victoria Land: Granite Harbour } \\
17 \text { Jan } 08 \text {, leg \& det: U. Ruprecht }\end{array}$ & R.Türk 43022 & GU074454 & GU074465 \\
\hline 8 & L. andersonii & $\begin{array}{l}\text { ANTARCTICA, Victoria Land: Mount Suess } \\
8 \text { Jan 08, leg \& det: U. Ruprecht }\end{array}$ & R. Türk 42995 & GU074447 & GU074458 \\
\hline 9 & L. andersonii & $\begin{array}{l}\text { ANTARCTICA, Victoria Land: Mount Suess } \\
8 \text { Jan 08, leg \& det: U. Ruprecht }\end{array}$ & R. Türk 42996 & GU074448 & GU074459 \\
\hline 10 & L. andersonii & $\begin{array}{l}\text { ANTARCTICA, Victoria Land: Sperm Bluff } \\
12 \text { Jan 08, leg \& det: U. Ruprecht }\end{array}$ & R. Türk 43002 & GU074449 & GU074460 \\
\hline 11 & L. andersonii & $\begin{array}{l}\text { ANTARCTICA, Victoria Land: Sperm Bluff } \\
12 \text { Jan 08, leg \& det: U. Ruprecht }\end{array}$ & R. Türk 43003 & GU074451 & GU074461 \\
\hline 12 & L. andersonii & $\begin{array}{l}\text { ANTARCTICA, Windmill Islands: Bailey Peninsula } \\
4 \text { Jan 89, leg \& det: R. Seppelt }\end{array}$ & ADT18513 & GU074443 & GU074468 \\
\hline 13 & L. andersonii & $\begin{array}{l}\text { ANTARCTICA, Windmill Islands: Bailey Peninsula } \\
25 \text { Dez 85, leg: R. Seppelt, det: U. Ruprecht }\end{array}$ & ADT24109 & GU074444 & GU074467 \\
\hline 14 & L. andersonii & $\begin{array}{l}\text { NORWAY, Svalbard: Ny Ålesund } \\
18 \text { Aug 08, leg: A. Tribsch, det: H. Hertel }\end{array}$ & R. Türk 43425 & GU074442 & GU074466 \\
\hline 15 & L. atrobrunnea (Ramond) Schaer. & $\begin{array}{l}\text { ANTARCTICA, Antarctic Peninsula: Danco Coast } \\
9 \text { Jan 06, leg \& det: M. Andreev }\end{array}$ & LE A060124 & GU074457 & GU074505 \\
\hline 16 & L. atrobrunnea & $\begin{array}{l}\text { ANTARCTICA, Antarctic Peninsula: Willhelm Archipelago } \\
12 \text { Jan 06, leg \& det: M. Andreev }\end{array}$ & LE A060414 & - & GU074504 \\
\hline 17 & L. atrobrunnea & $\begin{array}{l}\text { ANTARCTICA, South Shetland Island: Livingston Island } \\
3 \text { Feb 02, leg \& det: R. Türk }\end{array}$ & R.Türk 36121 & GU074455 & GU074509 \\
\hline 18 & L. atrobrunnea & $\begin{array}{l}\text { N. GREENLAND: near Nikolaj Nielsen Kyst, } \\
22 \text { Jul 99, leg \& det: E.S. Hansen }\end{array}$ & $\begin{array}{l}\text { Lund, Lich. Groenl. } \\
\text { Exsiccati } 770\end{array}$ & EU259897 & GU074510 \\
\hline 19 & $\begin{array}{l}\text { L. atrobrunnea ssp. saxosa } \\
\text { Hertel \& Leuckert (Ramond) Schaer. }\end{array}$ & $\begin{array}{l}\text { USA, California: Peninsula Range, Tahquitz Peak } \\
4 \text { Oct } 04 \text {, leg \& det: K. Knudsen }\end{array}$ & $\begin{array}{l}\text { U.C. Riverside } \\
\text { UCR-174803 }\end{array}$ & GU074456 & GU074507 \\
\hline 20 & L. atrobrunnea ssp. saxosa & $\begin{array}{l}\text { USA, California: Peninsula Range, Tahquitz Peak } \\
4 \text { Oct } 04 \text {, leg \& det: K. Knudsen }\end{array}$ & $\begin{array}{l}\text { U.C. Riverside } \\
\text { UCR-176128 }\end{array}$ & EU259898 & GU074508 \\
\hline 21 & $\begin{array}{l}\text { L. atrobrunnea ssp. stictica } \\
\text { Hertel \& Leuckert (Ramond) Schaer. }\end{array}$ & $\begin{array}{l}\text { AUSTRIA, Kärnten: Hohe Tauern } \\
2 \text { Jul 03, leg \& det: R. Türk }\end{array}$ & R. Türk 34435 & EU259899 & GU074506 \\
\hline 22 & L. auriculata $\mathrm{Th}$. Fr & $\begin{array}{l}\text { NORWAY, Svalbard: Ny Ålesund } \\
18 \text { Aug 08, leg: A. Tribsch, det: H. Hertel }\end{array}$ & R. Türk 43426 & GU074428 & GU074499 \\
\hline 23 & L. auriculata & SWEDEN, Jämtland: Åre par., Handöl & Lund L05184 & GU074427 & GU074500 \\
\hline
\end{tabular}


Table II. Continued

\begin{tabular}{|c|c|c|c|c|c|}
\hline No. & Name of species & Sample & Herbarium & ITS & $\mathrm{mtSSU}$ \\
\hline 24 & L. cancriformis Dodge \& Baker & $\begin{array}{l}\text { ANTARCTICA, Northern Victoria Land: Cape Hallett } \\
28 \text { Nov 04, leg: R. Seppelt, det: U. Ruprecht }\end{array}$ & ADT25151 & GU074429 & GU074477 \\
\hline 25 & L. cancriformis & $\begin{array}{l}\text { ANTARCTICA, Princess Elizabeth Land: Larssemann Hills } \\
2 \text { Jan 05, leg \& det: M. Andreev }\end{array}$ & LE A057501 & GU074440 & GU074479 \\
\hline 26 & L. cancriformis & $\begin{array}{l}\text { ANTARCTICA, Ross Dependency: Bartrum Basin } \\
16 \text { Jan 09, leg: R. Türk, det: U. Ruprecht }\end{array}$ & R. Türk 44712 & GU074438 & GU074487 \\
\hline 27 & L. cancriformis & $\begin{array}{l}\text { ANTARCTICA, Ross Dependency: Darwin Glacier } \\
26 \text { Jan 09, leg: R. Türk, det: U. Ruprecht }\end{array}$ & R. Türk 44634 & GU074434 & GU074486 \\
\hline 28 & L. cancriformis & $\begin{array}{l}\text { ANTARCTICA, Ross Dependency: Darwin Glacier-Brown Hills } \\
11 \text { Dec 04, leg: R. Türk, det: U. Ruprecht }\end{array}$ & R. Türk 35604 & EU257671 & GU074480 \\
\hline 29 & L. cancriformis & $\begin{array}{l}\text { ANTARCTICA, Ross Dependency: Lake Wellman } \\
4 \text { Dec 07, leg: R. Türk, det: U. Ruprecht }\end{array}$ & R. Türk 42988 & GU074435 & GU074481 \\
\hline 30 & L. cancriformis & $\begin{array}{l}\text { ANTARCTICA, Ross Dependency: Lake Wellman } \\
6 \text { Dec 07, leg: R. Türk, det: U. Ruprecht }\end{array}$ & R. Türk 42992 & GU074436 & GU074482 \\
\hline 31 & L. cancriformis & $\begin{array}{l}\text { ANTARCTICA, Ross Dependency: Mount Kyffin } \\
8 \text { Jan 03, leg \& det: L. Sancho }\end{array}$ & MAF-Sancho 2 & GU074439 & GU074489 \\
\hline 32 & L. cancriformis & $\begin{array}{l}\text { ANTARCTICA, Ross Dependency: Smith Valley } \\
15 \text { Dec 07, leg: M. Stevens, det: U. Ruprecht }\end{array}$ & R. Türk 44727 & GU074437 & GU074488 \\
\hline 33 & L. cancriformis & $\begin{array}{l}\text { ANTARCTICA, Victoria Land: Discovery Bluff } \\
19 \text { Jan 08, leg \& det: U. Ruprecht }\end{array}$ & R. Türk 43020 & GU074431 & GU074484 \\
\hline 34 & L. cancriformis & $\begin{array}{l}\text { ANTARCTICA, Victoria Land: Discovery Bluff } \\
19 \text { Jan 08, leg \& det: U. Ruprecht }\end{array}$ & R. Türk 43023 & GU074432 & GU074485 \\
\hline 35 & L. cancriformis & $\begin{array}{l}\text { ANTARCTICA, Victoria Land: Granite Harbour } \\
22 \text { Jan 08, leg \& det: U. Ruprecht }\end{array}$ & R. Türk 43028 & GU074430 & - \\
\hline 36 & L. cancriformis & $\begin{array}{l}\text { ANTARCTICA, Victoria Land: Mount Suess } \\
\text { 09 Jan 08, leg \& det: U. Ruprecht }\end{array}$ & R. Türk 43000 & GU074433 & GU074483 \\
\hline 37 & L. cancriformis & $\begin{array}{l}\text { ANTARCTICA, Victoria Land: Taylor Valley } \\
23 \text { Jan 03, leg: R. Türk, det: U. Ruprecht }\end{array}$ & R. Türk 33712 & EU257677 & GU074478 \\
\hline 38 & L. confluens (Weber) Ach. & $\begin{array}{l}\text { AUSTRIA, Salzburg: Lungau } \\
12 \text { Jul 06, leg \& det: R. Türk }\end{array}$ & R. Türk 39641 & EU263921 & GU074492 \\
\hline 39 & L. fuscoatra (L.) Ach. & $\begin{array}{l}\text { AUSTRIA, Oberösterreich: Eferding } \\
8 \text { Aug 06, leg \& det: F. Berger }\end{array}$ & R. Türk 40136 & EU263922 & GU074490 \\
\hline 40 & L. fuscoatrina Hertel \& Leuckert & $\begin{array}{l}\text { USA, California: Peninsula Range, Tahquitz Peak } \\
13 \text { May } 05 \text {, leg \& det: K. Knudsen }\end{array}$ & $\begin{array}{l}\text { U.C. Riverside } \\
\text { UCR (646Kerry) }\end{array}$ & EU259900 & - \\
\hline 41 & L. laboriosa Müll.Arg. & $\begin{array}{l}\text { USA, California: Peninsula Range, Tahquitz Peak U.C. Riverside } \\
21 \text { Aug 06, leg \& det: K. Knudsen }\end{array}$ & $\begin{array}{l}\text { EU259902 } \\
\text { 43266UCR1 }\end{array}$ & GU074503 & \\
\hline 42 & L. lapicida var. lapicida (Ach.) Ach. & $\begin{array}{l}\text { AUSTRIA, Osttirol: Hohe Tauern, } \\
21 \text { Jul 07, leg \& det: R. Türk }\end{array}$ & R. Türk 42745 & GU074425 & GU074493 \\
\hline 43 & L. lapicida var. pantherina Ach. & $\begin{array}{l}\text { AUSTRIA } \\
1997 \text { Hafellner \& Hafellner } \\
\text { AUSTRIA, Tirol: Ötztal } \\
8 \text { Jun 07, leg \& det: R. Türk }\end{array}$ & $\begin{array}{l}\text { GZU Hafellner } 42375 \\
\text { R. Türk } 42143\end{array}$ & AF332118 & GU074494 \\
\hline 44 & L. obluridata (L.) Nyl. & $\begin{array}{l}\text { AUSTRIA, Osttirol: Hohe Tauern } \\
21 \text { Jul 07, leg \& det: R. Türk }\end{array}$ & R. Türk 42730 & GU074423 & GU074495 \\
\hline 45 & L. plana (J.Lahm in Körb) Nyl & $\begin{array}{l}\text { SWEDEN, Halland: Veinge-Tjärby } \\
26 \text { Aug 03, det: U. Arup }\end{array}$ & $\begin{array}{l}\text { Herbarium Lund } \\
\text { L03170 }\end{array}$ & EU259903 & GU074497 \\
\hline
\end{tabular}


Table II. Continued

\begin{tabular}{|c|c|c|c|c|c|}
\hline No. & Name of species & Sample & Herbarium & ITS & $\mathrm{mtSSU}$ \\
\hline 46 & L. plana & $\begin{array}{l}\text { SWEDEN, Halland: Veinge-Tjärby } \\
19 \text { Sep 03, det: U. Arup }\end{array}$ & $\begin{array}{l}\text { Herbarium } \\
\text { Lund L03316 }\end{array}$ & EU259904 & GU074498 \\
\hline 47 & $\begin{array}{l}\text { L. polypycnidophora } \\
\text { Ruprecht \& Türk sp. nov. }\end{array}$ & $\begin{array}{l}\text { ANTARCTICA, Mac. Robertson Land: Prince Charles Mountains } \\
28 \text { Jan 05, leg: M. Andreev, det: U. Ruprecht }\end{array}$ & SZU A0513002 & GU074441 & GU074474 \\
\hline 48 & L. polypycnidophora & $\begin{array}{l}\text { ANTARCTICA, Victoria Land: Taylor Valley } \\
3 \text { Feb 2003, leg: R. Türk, det: U. Ruprecht }\end{array}$ & SZU Türk 33632 & EU257681 & GU074471 \\
\hline 49 & L. polypycnidophora & $\begin{array}{l}\text { ANTARCTICA, Victoria Land: Taylor Valley } \\
3 \text { Feb 2003, leg: R. Türk, det: U. Ruprecht }\end{array}$ & R. Türk 33640 & EU257682 & GU074473 \\
\hline 50 & L. polypycnidophora & $\begin{array}{l}\text { ANTARCTICA, Victoria Land: Taylor Valley } \\
25 \text { Jan 2003, leg: R. Türk, det: U. Ruprecht }\end{array}$ & R. Türk 33648 & EU257680 & GU074472 \\
\hline 51 & L. silacea (Hoffm.) Ach. & $\begin{array}{l}\text { AUSTRIA, Tirol: Ötztal } \\
8 \text { Jun } 07 \text {, leg \& det: R. Türk }\end{array}$ & R. Türk 42156 & GU074424 & GU074496 \\
\hline 52 & Lecidea sp. & $\begin{array}{l}\text { NORWAY, Svalbard: Ny Ålesund } \\
18 \text { Aug 08, leg: A. Tribsch }\end{array}$ & R. Türk 43427 & GU074426 & GU074502 \\
\hline 53 & Lecidea sp. & $\begin{array}{l}\text { USA, South Dakota: Brule County } \\
8 \text { Aug 03, leg: J.C. Lendemer, det: R.C. Harris }\end{array}$ & $\begin{array}{l}\text { Lichens of South Dakota } \\
\# 1165\end{array}$ & EU263929 & GU074501 \\
\hline 54 & L. tesselata Flörke & $\begin{array}{l}\text { AUSTRIA, Steiermark: Eisenerzer Alpen } \\
2 \text { Oct } 99 \text {, leg \& det: J. Hafellner }\end{array}$ & GZU Hafellner 49249 & EU263926 & GU074491 \\
\hline 55 & Lecidea UCR1 & $\begin{array}{l}\text { ANTARCTICA, Victoria Land: Taylor Valley } \\
3 \text { Feb 03, leg: R. Türk, det: U. Ruprecht }\end{array}$ & R. Türk 33619 & EU263927 & GU074475 \\
\hline 56 & Lecidea UCR1 & $\begin{array}{l}\text { ANTARCTICA, Victoria Land: Taylor Valley } \\
22 \text { Jan 03, leg: R. Türk, det: U. Ruprecht }\end{array}$ & R. Türk 33704 & EU263928 & GU074476 \\
\hline 57 & $\begin{array}{l}\text { Porpidia macrocarpa (DC.) } \\
\text { Hertel \& A. J. Schwab }\end{array}$ & $\begin{array}{l}\text { AUSTRIA, Salzburg: Lungau, } \\
14 \text { July 2005, leg \& det: R. Türk }\end{array}$ & R. Türk 39740 & EU263923 & GU074512 \\
\hline
\end{tabular}




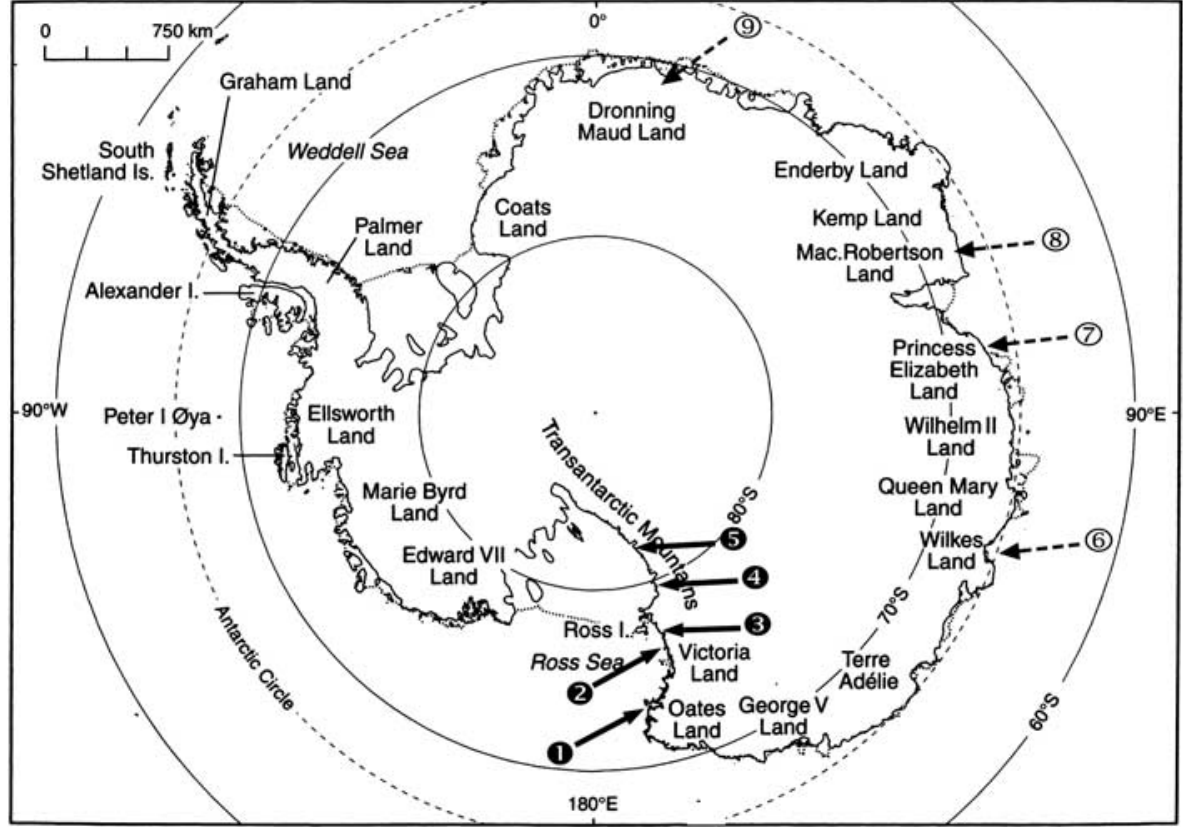

Fig. 1. Investigation areas, general map from Øvstedal \& Lewis Smith (2001). $1-5=$ Ross Sea area from $72^{\circ}-84^{\circ} \mathrm{S}$, the samples were collected by the authors and collaborators, $6=$ Wilkes Land (R. Seppelt), 7 = Princess Elizabeth Land (M. Andreev), $8=$ Mac Robertson Land (M. Andreev), and 9= Dronning Maud Land (M. Andreev). are the largest ice free areas in continental Antarctica (Doran et al. 2002). The region is a cold desert with arid soils and exposed bedrocks. Possible sources of water in this region are perennially ice covered lakes, snow (falling and blowing), clouds and fog, ephemeral streams and alpine glaciers (Doran et al. 2002).

4. a. Brown Hills $\left(79^{\circ} 46^{\prime}-79^{\circ} 50^{\prime} \mathrm{S} 158^{\circ} 33^{\prime}-195^{\circ} 25^{\prime} \mathrm{E}\right)$, 400-450 m alt., December 2004

The Brown Hills are located in the north of Darwin Glacier. The Carlyon granodiorite makes up most of the Brown Hills and includes a variably foliated, biotite-hornblende granodiorite and granite (Simpson \& Cooper 2002). This site appears to be a particularly dry part of the continental Transantarctic Range.

b. Lake Wellman (79 $\left.54^{\prime} \mathrm{S}, 1^{\circ} 6^{\circ} 32^{\prime}-156^{\circ} 53^{\prime} \mathrm{E}\right)$ 935-1371 m alt., November 2007

The surroundings of Lake Wellman are characterized by a very dry climate, caused by a high evaporation rate due to low average air humidity and/or continuous winds originating from the cold glacier regions. The bedrock surrounding this area is sandstone from the Beacon Group and dolerite from the Ferrar dolerite sills.

c. Diamond Hill $\left(79^{\circ} 51^{\prime}-79^{\circ} 52^{\prime} \mathrm{S}, 159^{\circ} 16^{\prime}-159^{\circ} 21^{\prime} \mathrm{E}\right)$, 371-550 m alt., January 2009

Diamond Hill is located at the eastern edge of the Transantarctic Mountains, close to the Ross Ice Shelf and north from the Darwin Glacier. Climate conditions are characterized by higher air humidity and precipitation that support a higher diversity and abundance of lichens.

d. Bartrum Basin $\left(79^{\circ} 45^{\prime} \mathrm{S}, \quad 158^{\circ} 30^{\prime}-158^{\circ} 38^{\prime} \mathrm{E}\right)$ 370-430 m alt, January 2009
Located in the north-west of the Brown Hills, Bartrum Basin is apparently very dry. The dominant rock types are dolerite and granite.

5. Mount Kyffin and surroundings, Queen Maud Mountains $\quad\left(83^{\circ} 44^{\prime}-83^{\circ} 45^{\prime} \mathrm{S}, \quad 172^{\circ} 15^{\prime}-172^{\circ} 46^{\prime} \mathrm{E}\right)$, $450-820 \mathrm{~m}$ alt., January 2003

The investigated area is located at the southern edge of Beardsmore Glacier. The mountains are formed by Goldie formation greywacke (Gunn \& Walcott 1962) and schist. The collecting sites at the ridges were snow free. The site is characterized by low precipitation rates and severe winters.

\section{Morphological analyses}

Light microscopic investigations were carried out with a LEITZ Laborlux S (Leitz, Vienna). Cross sections of apothecia (12 $\mu \mathrm{m}$ thick) were prepared using a Leitz Kryomat 1703 freezing microtome. The sections were stained with Lactophenol blue solution, $\mathrm{KOH}(10 \%)$ and Lugol's iodine solution $50 \%$. Thallus morphology, anatomical features of asci and the ascospores were documented with photographs, using a digital camera (Samsung-Digimax V50).

\section{Chemical analyses}

Samples were extracted for four hours in methanol and secondary compounds were characterized by high-performance liquid chromatography (HPLC) using benzoic acid and (E)-1-(9-Anthryl)-2-phenylethene as internal standards. HPLC analyses were performed according to Stocker-Wörgötter \& Elix (2002) using a Hitachi /Merck Spectra System with a Beckman $5 \mathrm{C} 18$ column, 250 by $4.6 \mathrm{~mm}$, with spectrometric 


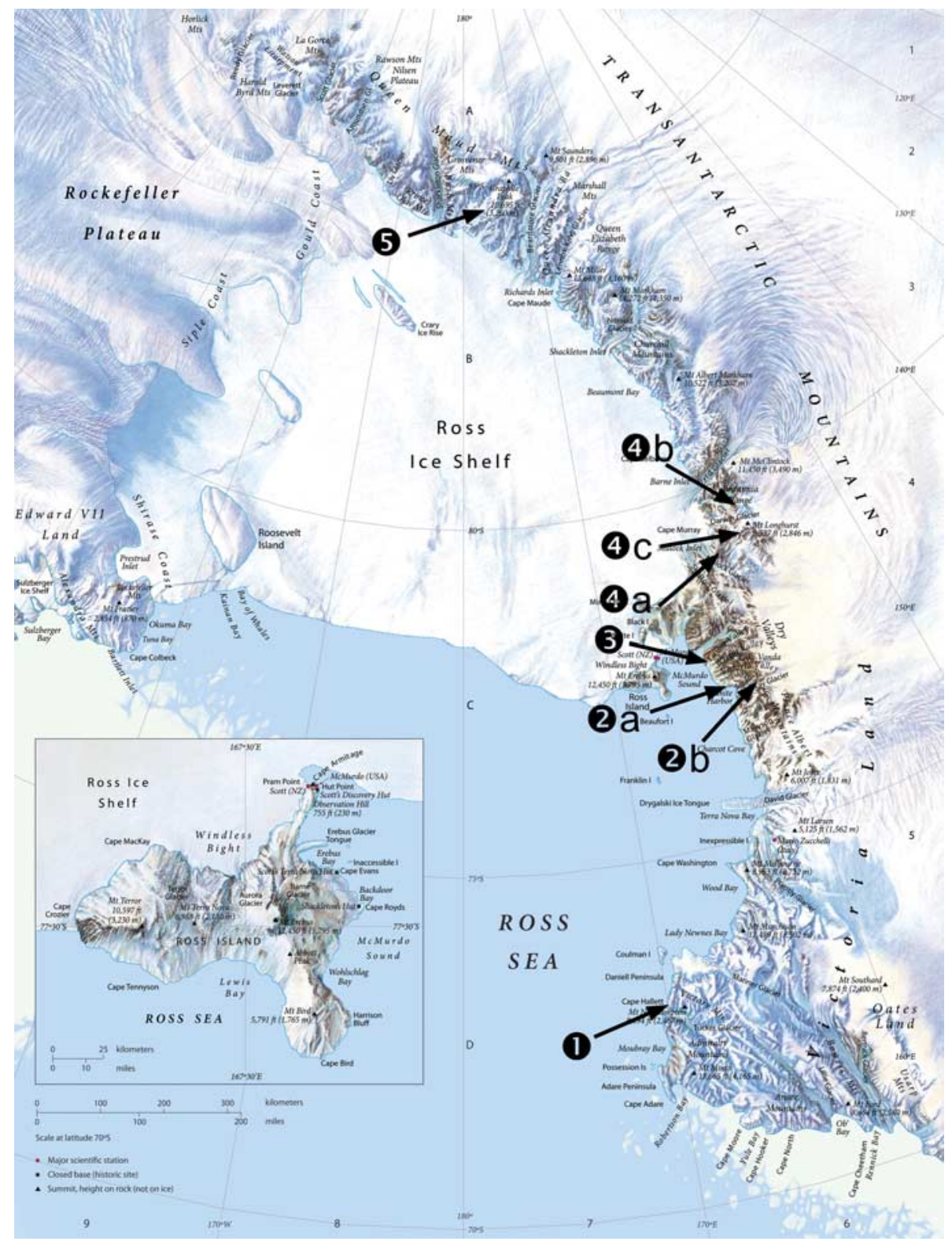

Fig. 2. More detailed view on the snow free regions of the Ross Sea coast at the end of summer (McGonigal \& Woodworth 2001). 1 = Cape Hallett, $2 \mathrm{a}=$ Granite Harbour-Botany Bay-Discovery Bluff, $2 \mathrm{~b}=$ Mount Suess-Sperm Bluff, $3=$ Taylor Valley, $4 \mathrm{a}=$ Brown Hills, $4 \mathrm{~b}=$ Lake Wellman, $4 \mathrm{c}=$ Diamond Hill-Bartrum Basin. detectors operating at $254 \mathrm{~nm}$ with a flow rate of $1 \mathrm{ml} \mathrm{min} \mathrm{m}^{-1}$.

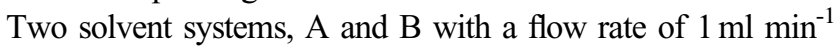
were used as follows: The run started with 100\% A (1\% aqueous ortho-phosphoric acid and methanol in the ratio 7:3) and was raised to $58 \% \mathrm{~B}$ (pure methanol) over $15 \mathrm{~min}$, then to $100 \% \mathrm{~B}$ over a further $15 \mathrm{~min}$, followed by isocratic elution in $100 \%$ B for further $10 \mathrm{~min}$.

Standardized TLC with atranorin and norstictic acid as reference substances and solvents $\mathrm{A}, \mathrm{B}$ ' and $\mathrm{C}$ was used to identify the chemical profile of the lichens (Culberson \& Johnson 1982 and references therein).

\section{DNA-amplification, purification, sequencing}

Total DNA was extracted from thallus or apothecia by using the DNeasy Plant Mini Kit (Qiagen) according to the manufacturer's instructions. The PCR mix contained 0.5 units of recombinant Taq polymerase (Fermentas), $0.2 \mathrm{nM}$ of each of the four dNTPs, $0.3 \mu \mathrm{M}$ of each primer and $1-10 \mathrm{ng}$ genomic DNA. The PCR products were purified using Qiaquick PCR purification kit (Qiagen) and resolved in sterile distilled water. The purified and dried PCR-products were sent to Macrogen (Seoul, Korea) for sequencing using the PCR primers. The obtained sequences were aligned with homologous sequences from the NCBI-Database. In cases where the PCR did not produce bands in a first reaction, we took $1 \mu$ l of this reaction for a nested PCR with internal primers. Reactions that produced multiple bands were taken for TA cloning. Plasmids were isolated using the Wizard Plus SV Miniprep System (Promega) and inserts were sequenced.

The internal transcribed spacer region (ITS) of the mycobionts' nuclear ribosomal DNA and mitochondrial 
Table III. Sequences, temperature and primer map of the used ITS-primers.

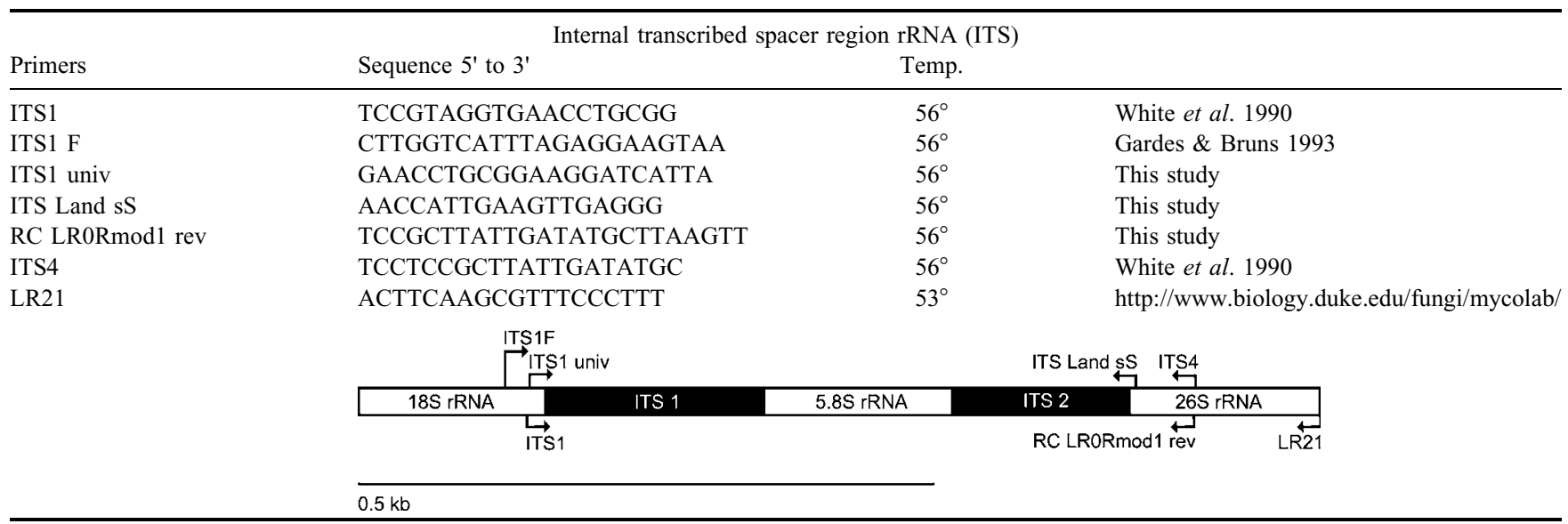

small subunit (mtSSU) were amplified and sequenced with the primers described in Tables III \& IV. To reduce the costs for sequencing and to accelerate the identification of the large number of $L$. andersonii samples - often more than 20 years old, we designed 'ITS-Land sS' (Table III), a reverse primer to directly and specifically amplify the ITS region of $L$. andersonii, best used with ITS-1F. To be certain that this primer amplified only $L$. andersonii, we tested it on already confirmed $L$. andersonii specimens and on other Lecidea species throughout the phylogeny and sequenced the products.

\section{Phylogenetic analysis}

Mitochondrial SSU and nuclear ITS sequences were assembled with vector NTI Advance 9 (Invitrogen, Vienna, Austria) and then manually corrected. The alignment of sequences (including out-group taxon) was done using MacClade (Maddison \& Maddison 2003).

The alignment was unambiguous and included only a few gaps. For comparison, lecideoid species from other regions of Antarctica and other parts of the world were sequenced and included in the data matrix together with one sequence downloaded from Genbank as shown in Table II. To test for potential conflict, parsimony bootstrap analyses were performed on each individual dataset, and $75 \%$ bootstrap consensus trees were examined for conflict.

To choose a nucleotide substitution model we used Modeltest 3.7 (Posada \& Crandall 1998); both tests (hierarchical likelihood ratio test and Akaike information criterion) selected the Tamura-Nei Model (TrNef) with equal base frequencies including estimation of invariant sites and assuming a discrete gamma distribution. A maximum likelihood analysis (ML) was performed using the program Garli 0.96 (http://www.nescent.org/wg_garli/Main_Page)

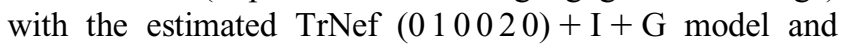
default settings. Nonparametric bootstrap was used to assess robustness of clades, running 2000 pseudo replicates.

Maximum parsimony analyses (MP) were performed using the program PAUP* (Swofford 2003). Heuristic searches with 1000 random taxon addition replicates were conducted with TBR branch swapping and MulTrees option in operation,

Table IV. Sequences, temperature and primer map of the used mtSSU-primers.

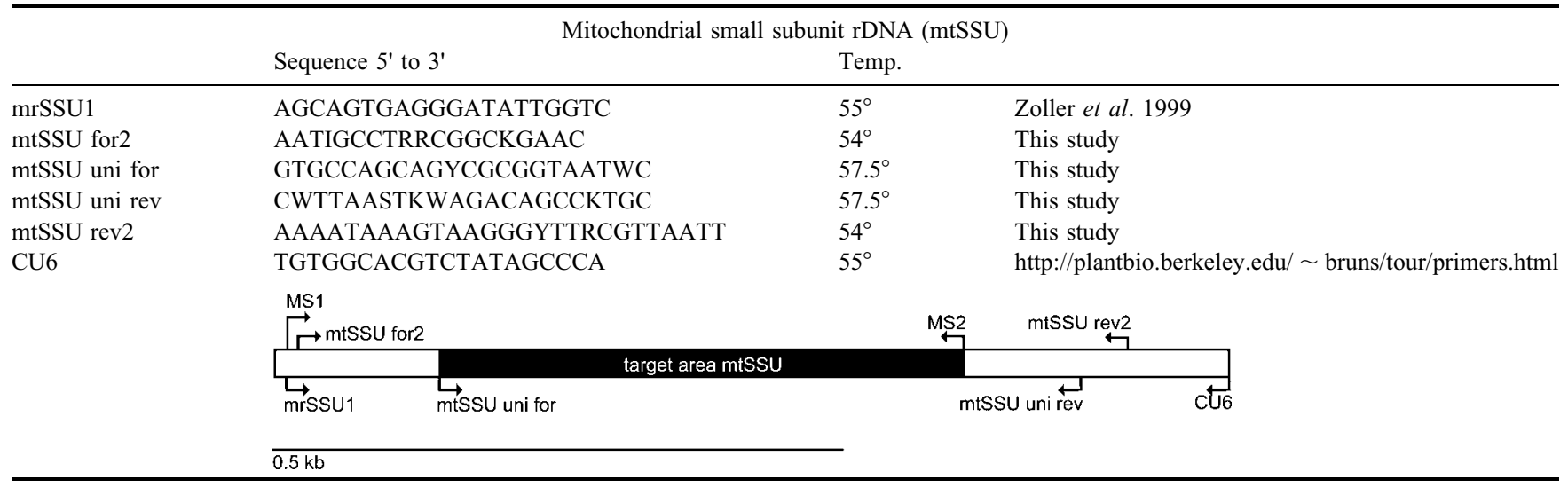




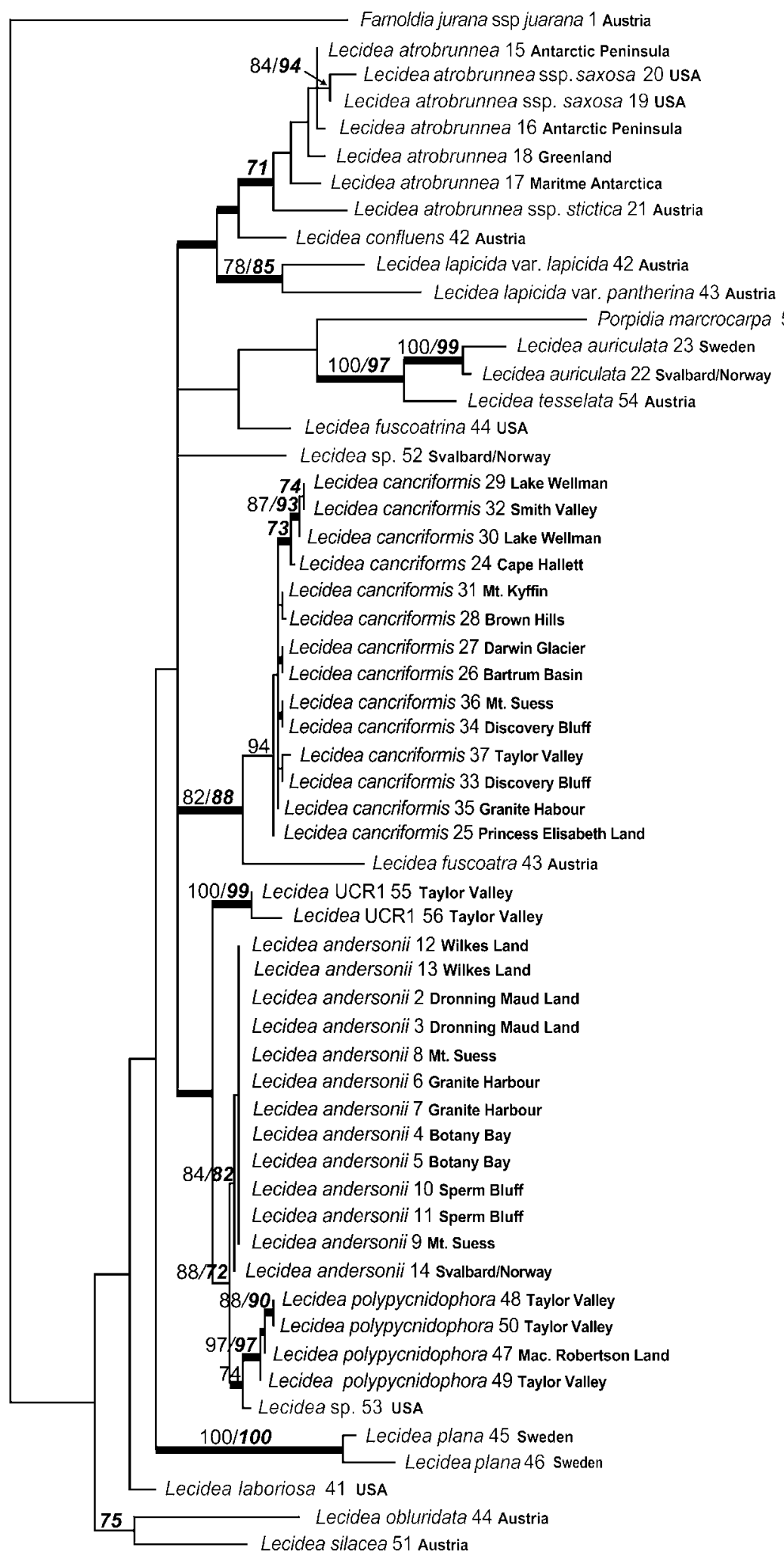

-5 changes [nil

2'-0-methylperiatolic acid

conorstictic.

norstictic acid

confluentic, 2'-O-methylperlatolic acid

$\square \mathrm{nil}$

2'-O-methyjperiatolic acid

stictic acid

confluentic acid

stictic chemosyndrome

0 not det.

stictic acid

nil

confluentic acio

confiuentic, 2'-O-methyiperlatolic acid

stictic acid

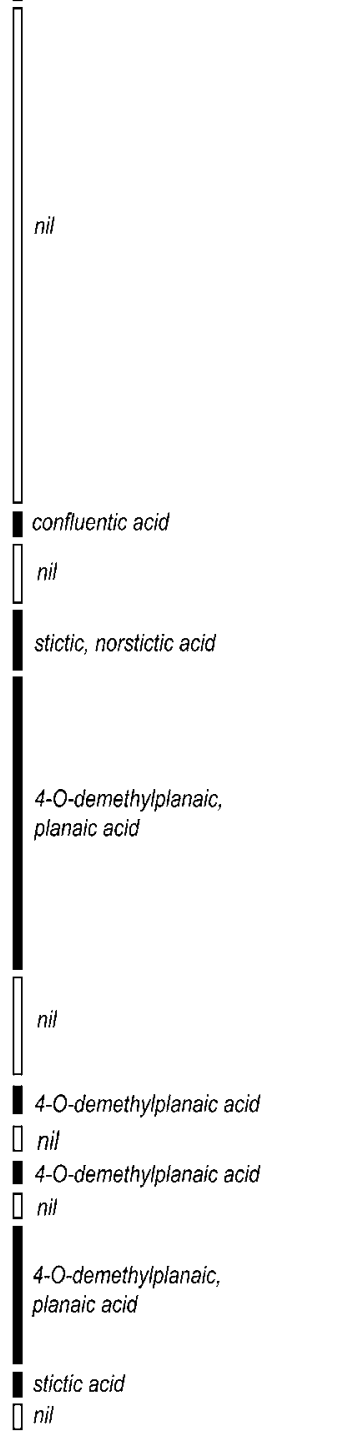

MP/ML/MrBayes > 0.95

Fig. 3. Phylogeny of Antarctic Lecidea spp. This Bayesian tree is based on a combined dataset of ITS and mtSSU with $>0.95$ support and directly mapped bootstrap values with $>70$ support of maximum parsimony - and maximum likelihood (Garli 0.96) analysis. Secondary metabolites of the specimens are plotted to the right of the tree. The four main clades are indicated in black. 

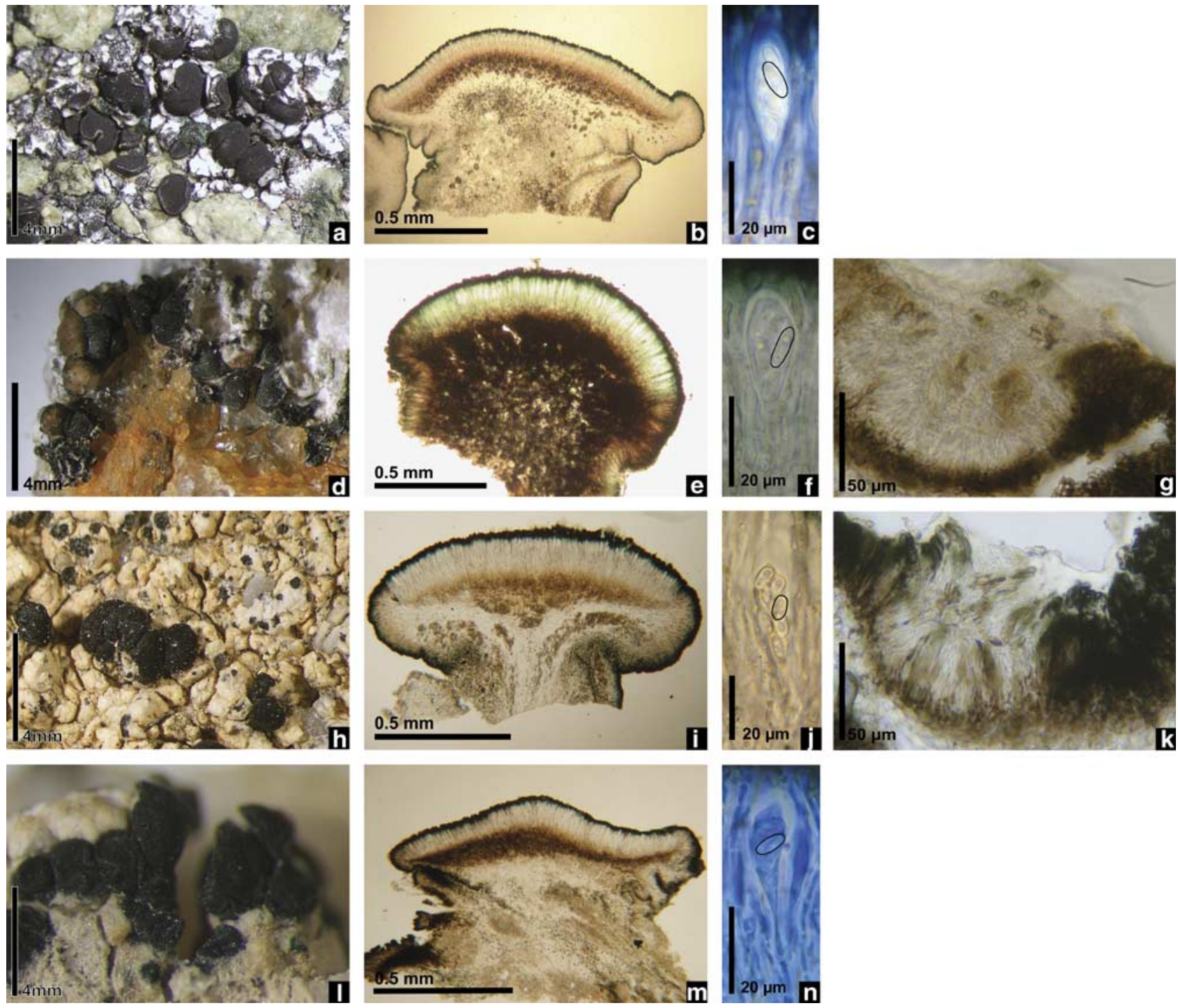

Fig. 4. Overview of the most important morphological attributes of the investigated Lecidea specimens. Lecidea andersonii:

a. Sparse thallus with apothecia, b. cross-section of apothecium, c. ascus with narrowly ellipsoid ascospores. Lecidea cancriformis: d. brownish thallus with apothecia and a dense group pycnidia bottom left, e. cross-section of apothecium with characteristically dark brown hypothecium, f. ascus with narrow oblong ascospores, g. cross-section of pycnidium with bacilliform conidia. Lecidea polypycnidophora sp. nov.: h. thallus with apothecia and abundant pycnidia, i. cross-section of apothecium, j. ascus with ellipsoid ascospores, $\mathbf{k}$. cross-section of pycnidium with bacilliform pycnospores. Lecidea UCR1: l. chasmolithic thallus with aggregated apothecia, m. cross-section of apothecium, n. ascus with narrowly ellipsoid ascospores.

equally weighted characters and gaps treated as missing data. Bootstrapping was performed based on 2000 replicates with random sequence additions. Homoplasy levels were assessed by calculating consistency index (CI), retention index (RI), and rescaled consistency (RC) index from each parsimony search.

The B/MCMC analyses were conducted using the MrBayes 3.1. program (Huelsenbeck \& Ronquist 2001). A run with 10000000 generations starting with a random tree and employing four simultaneous chains was executed. Every 100th tree was saved into a file. The first 1000000 generations (i.e. the first 10000 trees) were deleted as the "burn in" of the chain. We plotted the log-likelihood scores of sample points against generation time using TRACER 1.0 (http://evolve.zoo.ox.ac.uk/software.html?id=tracer) to check whether stationarity was achieved after the first 1000000 generations by checking whether the log-likelihood values of the sample points reached a stable equilibrium value (Huelsenbeck \& Ronquist 2001). Additionally, we used AWTY (Nylander et al. 2007) to compare splits frequencies in the different runs and to plot cumulative split frequencies to ensure that stationarity was reached. Of the remaining 
180000 trees (90000 from each of the parallel runs) a majority rule consensus tree with average branch lengths was calculated using the sumt option of MrBayes. Posterior probabilities were obtained for each clade. Only clades that received bootstrap support equal, or above, $70 \%$ under parsimony, and likelihood and posterior probabilities equal, or above, 0.95 were considered as strongly supported.

\section{Results}

\section{Phylogenetic analyses}

In total four different Lecidea species could be identified in continental Antarctica and are confirmed by morphological, chemotaxonomic and molecular data including two novel Lecidea species. As well as our own material freshly collected at various sites in areas of continental Antarctica we could also use comparison material of Lecidea, most of which included originally described species treated in this study. The new sequences were aligned with one ITS sequence downloaded from Genbank (Table II).

After excluding excess sequences the final data matrix for the molecular phylogeny comprised 57 OTUs. The length of the combined alignment (mitochondrial SSU and nuclear ITS rDNA) was 877 unambiguously aligned nucleotide position characters. The MP $75 \%$ bootstrap support method for testing datasets for incongruence indicated no strongly supported conflict (data not shown) and hence a combined analysis was performed.

164 positions in the combined alignment were parsimonyinformative. MP analyses yielded 298 most parsimonious trees 683 steps long $(\mathrm{CI}=0.59, \mathrm{RI}=0.74, \mathrm{RC}=0.44)$. Tree topologies among maximum parsimony, maximum likelihood and Bayesian analyses were identical in all well-supported clades and so we only present here the Bayesian tree with support values of the other analyses (Fig. 3).

The phylogenetic reconstruction indicates that the samples from continental Antarctica cluster in four well supported clades. Specimens identified as $L$. cancriformis form a monophyletic group that has an unsupported relationship to $L$. fuscoatra. The specimens of $L$. andersonii form one monophyletic group, which contains three chemotypes (stictic/norstictic acid, planaic/4-o-demethylplanaic acid, no secondary metabolites) and a sample from Svalbard (Norway). In addition to these two species, two currently unnamed clades were found and are described below. These are Lecidea UCR1 and L. polypycnidophora. The two samples of Lecidea sp. (L. UCR1) form a strongly supported monophyletic group and are sister to the two clades including specimens of $L$. andersonii, L. polypycnidophora and an unidentified Lecidea $\mathrm{sp}$. from South Dakota (USA). Lecidea polypycnidophora with the sequence of the lichen sample LOSD1165 (South Dakota, USA) at the base, form a sister group to $L$. andersonii. The results of this phylogenetic analysis indicates that four distinct lineages of Lecidea spp. occur in continental Antarctica.

The backbone of the phylogeny is not supported and so this analysis does not allow further conclusions regarding the relationships of the species examined. However, the additional samples from Antarctica form strongly supported clades for each of the currently described species. Lecidea atrobrunnea, L. lapicida, L. plana, L. tesselata and L. auriculata each form clearly defined and well supported monophyletic groups. The currently accepted varieties - including different chemotypes in two of the species (L. atrobrunnea, L. lapicida), however, are more distantly related and form different clades in our analyses as can be seen in the chemotypes plotted on the phylogenetic tree in Fig. 3. The species of the genus Porpidia are nested within Lecidea as shown in previous studies (Buschbom \& Barker 2006).

\section{Morphological and chemical analyses}

Based on the sequence data from 170 Lecidea samples (Table I), we re-examined the morphology and secondary chemistry to identify phenotypic characters that circumscribe the monophyletic clades found in the analysis. We got a complete dataset of molecular, chemical and morphological analyses from a total of 107 specimens. 57 accessions were chosen to build up the final phylogeny after excluding additional accessions of the same species from identical habitats.

The localities of the studied specimens and herbarium information are given in Tables I \& II. The most important diagnostic characters of the four Lecidea spp. in continental Antarctica are shown in Fig. 4. Descriptions of the species and discussion on variation and differences to similar species are given below.

\section{Lecidea andersonii Filson 1974}

Thallus: often poorly developed, rimose to areolate, up to $2 \mathrm{~cm}$ in diam., angular and usually adpressed along rock crevices; surface: whitish to grey and brownish; apothecia: frequent, scattered in groups, dense and partially grouped, sessile, constricted at the base, round to irregular, up to $2 \mathrm{~mm}$ in diam., disc black, flat to slightly convex, mostly epruinose, rarely with a thin whitish pruina, margin distinct, sometimes becoming flexuose; proper exciple: 80-150 $\mu \mathrm{m}$ high, hyaline, outer margin dark green to brownish green; hypothecium: brownish, $70-100 \mu \mathrm{m}$ high; hymenium: hyaline, $50-80 \mu \mathrm{m}$ high; paraphyses: simple, coherent, with swollen apices; epihymenium: dark green, 10-15 $\mu \mathrm{m}$ high; asci: amyloid, Lecidea-type, 8-spored; ascospores: narrowly ellipsoid (8-) 9-12 × 3-4, lengthwidth index 2,1-2,3; spot tests: thallus K-, C-, I- and medulla: K-, C-, I+ ; secondary metabolites: chemotype I: 4-O-demethylplanaic and planaic acids; chemotype II: stictic and norsticic acids; chemotype III: nil. 
Substrate: on siliceous rocks (granite).

Distribution: bipolar; known from maritime and continental Antarctica, Svalbard/Norway and Iceland. In continental Antarctica, L. andersonii occurs only in milder regions with coastal aspects. No specimens were found south of $77^{\circ}$ (see Figs $1 \& 3$ and Tables I \& II)

Notes: Our morpholpogical circumscription of Lecidea andersonii agrees with the current concept (Filson 1974, Øvstedal \& Lewis Smith 2001, Castello 2003, Hertel 2007, 2009). Inoue (1991) placed the species in the L. auriculata group where it is characterized by wide ascospores (Hertel 2007). Our phylogenetic analysis does not support this classification, but suggest a close relationship to Lecidea tesselata (Fig. 3). The results of our studies on the secondary chemistry of $L$. andersonii differ from that given in the literature. Previously, stictic acid (Hertel 2007) or confluentic and glomelliferic acids were reported for $L$. andersonii (Inoue 1991, Øvstedal \& Lewis Smith 2001). We could not detect confluentic and glomelliferic acids in any $L$. andersonii specimen (Fig. 3). Instead we found three chemotypes (see above) the most common possesses 4- $O$-demethylplanaic acid and planaic acid. We also studied two specimens from Wilkes Land (type locality) which were confirmed as belonging to $L$. andersonii using molecular data, but contained stictic and norstictic acids. This chemistry agrees with the literature (Hertel 2007). Noteworthy, the long side chain depsides 4-Odemethylplanaic and planaic acids are not biosynthetically related to the beta-orcinol depsidones of the stictic acid chemosyndrome. We included also a sample from Svalbard/ Norway (No. 14) in our calculations which could clearly be identified as $L$. andersonii by sequence and morphology. This specimen from Norway lacks secondary metabolites and hence represents a third chemotype together with two Antarctic specimens within this clade (Fig. 3).

Lecidea andersonii was long regarded as an Antarctic endemic (Øvstedal \& Lewis Smith 2001, Castello 2003) until Hertel (2007) placed Lecidea pseudopromiscens Hertel \& Rambold from Iceland into synonymy with L. andersonii. Our material from Svalbard/Norway confirms a bipolar distribution for this species.

Similar species in Antarctica include planaic and/or 4-O-demethylplanaic acid or lack secondary metabolites. $L$. andersonii is characterized by an I+ medulla, narrowly ellipsoid ascospores, mostly distinct margin and a sparsely developed thallus.

\section{Lecidea cancriformis C.W. Dodge \& G.E. Baker,} Ann. Mo. Bot. Gard. 25: 539 (1938)

Thallus: well developed, delimited, rimose to areolated and often sub-bullate, up to $3 \mathrm{~cm}$ in diam., often along crevices; surface: whitish (when eroded) to grey and brown; pycnidia: when present, grouped, with a black ostiolum, containing bacilliform conidia, up to $150 \mu \mathrm{m}$ in diam. Apothecia: scattered in groups, sessile, constricted at the base, up to $1.4 \mathrm{~mm}$ in diam., disc black, flat to moderately convex, round to irregular, margin thin, if present; proper exciple: up to $100 \mu \mathrm{m}$ thick, pale, outer margin dark green to brownish green; hypothecium: brown to black, $70-100 \mu \mathrm{m}$ high; hymenium: hyaline to pale green, 40-90 $\mu \mathrm{m}$ high; paraphyses: simple, septate, coherent, apices slightly swollen, $4-5 \mu \mathrm{m}$ thick; epihymenium: dark green, 10-20 $\mu \mathrm{m}$ high; asci: amyloid, Lecidea-type, 8-spored;

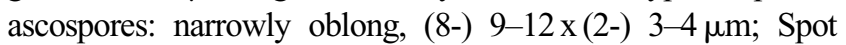
tests: thallus and medulla: K-, C-, I-; secondary metabolites: nil.

Substrate: on siliceous rock (granite).

Distribution: endemic to continental Antarctica (Øvstedal \& Lewis Smith 2001, Castello 2003, Hertel 2007).

Notes: This species has a whitish (necrotic), grey or brown thallus surface (Øvstedal \& Lewis Smith 2001, Hertel 2007), including variable forms with endolithic growth to thick, brownish glossy thalli. Material seen by Castello (2003) included only brown to dark brown or black thalli with a smooth and shiny surface. The taxon is readily distinguished by a negative iodine reaction of the medulla and the absence of orcinol depsides. The size of the hymenium $(40-90 \mu \mathrm{m}$ high) is in our study sometimes higher than previously described. Inoue (1991) indicated a height of 35-50 $\mu \mathrm{m}$, Øvstedal \& Lewis Smith (2001) of 60-65 $\mu \mathrm{m}$, Castello (2003) of $60-80 \mu \mathrm{m}$ and Hertel (2009) of 38-55 $\mu \mathrm{m}$, which shows a high variability. Hertel (2007) mentioned that numerous specimens contain norstictic acid but this was not found in our samples. Under the circumstance of extreme environmental factors (thallus eroded) the species is similar to $L$. polypycnidophora and $L$. UCR1, but readily distinguished by oblong ascospores, a dark brown hypothecium, an I- medulla and infrequent sub-bullate, brown areoles.

Lecidea cancriformis is a widespread species and occurs in every locality sampled in the Ross Sea region. It is especially dominant in dry parts, where it is accompanied by Acarospora gwynii and Lecanora fuscobrunnea (Stevens et al. unpublished, Marshall et al. unpublished)

\section{Lecidea polypycnidophora Ruprecht \& Türk sp. nov.}

Thallus crustosus, areolatus, rotundus, albidus. Medulla I+ violacea. Pycnidia abundantes. Apothecia aggregata, ad basin constricta, nigra, plana usque ad convexa. Hypothecium 30-40 $\mu \mathrm{m}$ altum. Hymenium hyalinum, 50-70 $\mu \mathrm{m}$ altum. Paraphyses simplices, septatae, apices turgidos. Epihymenium virido-nigrum, $15-20 \mu \mathrm{m}$ altum. Asci ad typum Lecidea pertinens. Ascosporae hyalinae, non-septatae, ellipsoidae, 6-8 x (3-) 4-5 $\mu \mathrm{m}$.

Type: Antarctica, a) Holotypus: Victoria Land: Taylor Valley, $25 \mathrm{~m}$ alt, $77^{\circ} 36^{\prime} 48.6^{\prime \prime S}, 163^{\circ} 04^{\prime} 18.4^{\prime \prime} \mathrm{E}$, leg. Roman Türk 33632 (SZU), b) Paratypus: Mac. Robertson Land: Prince 
Charles Mountains, Field Base Radok, $160 \mathrm{~m}$ alt, $70^{\circ} 49^{\prime} \mathrm{S}$, $68^{\circ} 05^{\prime} \mathrm{E}$, leg. Mikhail Andreev 0513002 (SZU).

Thallus: well developed, areolated, rounded to angular and partly granular, up to $1.5 \mathrm{~mm}$ thick, along crevices; surface: whitish to cream-coloured; pycnidia: either in dense groups at fissures or evenly distributed over the thallus, ostiolum grey to black, conidia bacilliform, up to $300 \mu \mathrm{m}$ in diam.; Apothecia: scattered in small groups, sessile, constricted at the base, round to irregular, up to $1.5 \mathrm{~mm}$ in diam., disc black, flat to convex, margin indistinct to distinct; proper exciple: broad, 150-250 $\mu \mathrm{m}$ thick, brownish, outer margin dark green to brownish green; hypothecium: mid-brown, 30-40 $\mu \mathrm{m}$ high; hymenium: hyaline, $50-70 \mu \mathrm{m}$ high; paraphyses: simple, septate, coherent, apices slightly swollen, 5-6 x $4 \mu \mathrm{m}$; epihymenium: dark green, 15-20 $\mu \mathrm{m}$ high; asci: amyloid, Lecidea-type, 8-spored; ascospores: ellipsoid, 6-8 x (3-) 4-5 $\mu \mathrm{m}$, length-width index: 1.4-1.9; spot tests: thallus K-, C-, I- and medulla: K-, C-, I+ faintly violet; secondary metabolites: 4-O-demethylplanaic acid or nil.

Substrate: on siliceous rocks (sandstone, granite).

Distribution: so far endemic to Continental Antarctica.

Notes: This new species has a well developed thallus with abundant pycnidia, a faintly violet I+ medulla and ellipsoid ascospores. It is similar to L. andersonii and Lecidea UCR1 but differs in having broader ascospores (length-width index 1.4-1.9 in comparison to $2.1-2.3$ and $\sim 2$ ), a well developed, visible thallus and pycnidia. Another similar species is L. soyaensis M. Inoue (Inoue 1991). However, this species has a sparsely developed thallus which is largely restricted to the surroundings of the apothecia, a violet-brown hypothecium, and a I+ intensively violet medulla. It further differs chemically in containing the stictic acid chemosyndrome (Hertel 2007) and is probably a synonym of $L$. andersonii.

Additional specimens examined: Antarctica, Victoria Land: Taylor Valley: Türk 33640 (No. 49), 33641, 33648 (No. 50), 33658, 33703.

"Incertae sedis" Lecidea sp.: Lecidea UCR1: Türk 33619 (No.54), Türk 33704 (N. 55)

Thallus: well developed, rimose to areolate, up to $1.5 \mathrm{~mm}$ high, along crevices; surface: whitish to grey and pale brown; apothecia: frequent, densely aggregated, sessile, constricted at the base, up to $1.2 \mathrm{~mm}$ in diam., disc black matt, flat, round to irregular, inconspicuous margin; proper exciple: broad, up to $200 \mu \mathrm{m}$ thick, hyaline, outer margin dark green; hypothecium: brown, seldom hyaline, 40-50 $\mu \mathrm{m}$ high; hymenium: hyaline, often with brownish granules, 40-60 $\mu \mathrm{m}$ high; paraphyses: simple, septate, coherent, apices slightly swollen, $4 \times 5-6 \mu \mathrm{m}$ thick; epihymenium: dark green to dark brown, $10-15 \mu \mathrm{m}$ high; asci: amyloid, Lecidea-type, 8-spored; ascospores: narrowly ellipsoid, (7-) 8-9 (-10) x (3-) 4 (-5) $\mu \mathrm{m}$, length-width index: $\sim 2$; spot tests: thallus and medulla: $\mathrm{K}-, \mathrm{C}-$, cortex $\mathrm{I}+$, medulla I- (Türk 33704), rarely I+ (Türk 33619); secondary metabolites: nil.

Substrate: on siliceous rock (granite).

Distribution: so far only known from two collections in Taylor Valley (continental Antarctica).

Notes: although morphological and molecular evidence suggest that these two samples belong to a distinct lineage, we refrain from formally describing this as a new species, because of some variability in the sequenced markers and in the lichen chemistry (iodine reaction of the medulla), until further samples become available.

These chasmolithic growing specimens have a welldeveloped, whitish thallus, densely grouped, sessile, black apothecia with an inconspicuous margin, a broad exciple and narrowly ellipsoid ascospores. They differ from $L$. andersonii by a mostly I- medulla, a well developed thallus and apothecia without a distinct margin. The ascospores are smaller than those of $L$. cancriformis. Further, the hypothecium is lighter in comparison to the dark brown in L. cancriformis. In comparison to the new species $L$. polypycnidophora are there no pycnidia, the thallus is completely covered with apothecia, and the ascospores are more oblong.

\section{Discussion}

Our analyses demonstrate that the diversity of Lecidea spp. in continental Antarctica is higher than previously thought. Geographical data evaluation also shows a decreasing diversity of Lecidea species the more continental and drier the habitats are (see Table II and Investigation Sites). It clearly indicates that the species concept in Lecidea needs revision and that molecular data are helpful in interpreting subtle morphological differences that have been previously regarded as intraspecific variability. Our combined approach of molecular analyses and morphological and chemical re-examination on the background of the phylogenetic estimate has led to the description of two new species here.

One of these new species, Lecidea polypycnidophora, forms a distinct well supported clade as a sister group to L. andersonii. Lecidea polypycnidophora can clearly be distinguished from its sister groups by its abundant pycnidia, the shape of the spores and a well developed thallus. The other strongly supported clade is formed by two accessions of a Lecidea species of uncertain status (Lecidea UCR1). We refrain here from formally describing the lichens in this clade as a single novel species because a very important character for identification (iodine reaction of the medulla) brings up two different results. Therefore we cannot say if this is just some variation within a single species or if there are two sub-species in this clade. Additionally there is at least some sequence variation between the two accessions within the $L$. UCR1 
clade but still it clearly forms a distinct strongly supported group.

These results agree with similar studies in other groups of lichenized fungi indicating that numerous distinct lineages are hidden under a single lichen-fungus name (Grube \& Kroken 2000, Kroken \& Taylor 2001, Molina et al. 2004, Arguello et al. 2007, Lücking et al. 2008, Wirtz et al. 2008). In these studies, morphological or chemical differences have been previously interpreted as intraspecific variability. Re-examination of morphology with the background of a molecular phylogenetic estimate then revealed, often subtle, morphological and/or chemical characters, supporting the distinction of these clades at species level. There is a growing body of evidence that the approach to current species recognition, which is largely based on morphology and chemistry, underestimates the number of species. Hence, there is a strong possibility that large numbers of undescribed fungal species will not only be found in poorly studied areas, such as tropical forests or in underexplored habitats, for example growing in insects, plants or lichens (Hawksworth \& Rossman 1997, Sipman \& Aptroot 2001, Arnold \& Lutzoni 2007), but also hidden under known species names.

\section{Acknowledgements}

The first author is thankful to Armin Hager (Salzburg) for the introduction into the HPLC analytical method. Jack Elix (Canberra) and Elfie Stocker-Worgötter (Salzburg) were helpful with the interpretation of HPLC-data. Valuable comments to our manuscript were given by Hans-Peter Comes (Salzburg) and Hannes Hertel (Munich). Finally, we would like to thank the collectors and curators of herbaria for sending us specimens for comparative investigations. Antarctica New Zealand is thanked for logistics support. Waikato University is thanked for financial support and, in particular Vice Chancellor Bryan Gould for encouraging and financing the programme and Vice Chancellor Roy Crawford for continuing this. TGA Green held a Ramon y Cajal award at Universidad Complutense, Madrid, for part of this work.

This paper is an output of the FRST-funded IPY Research Programme Understanding, valuing and protecting Antarctica's unique terrestrial ecosystems: Predicting biocomplexity in Dry Valley ecosystems located at Biological Sciences, Waikato University.

\section{References}

Andreev, M.P. 1990. Lichenes oasis Bangerii (Antarctis orientalis). Novitates Systematicae Plantarum non Vascularium, 27, 85-93.

Arguello, A., Del Prado, R., Cubas, P. \& Crespo, A. 2007. Parmelina quercina (Parmeliaceae, Lecanorales) includes four phylogenetically supported morphospecies. Biological Journal of the Linnean Society, 91, 455-467.

Arnold, A.E. \& Lutzoni, F. 2007. Diversity and host range of foliar fungal endophytes: are tropical leaves biodiversity hotspots? Ecology, 88, 541-549.
Broady, P.A. \& Weinstein, R.N. 1998. Algae, lichens and fungi in La Gorce Mountains, Antarctica. Antarctic Science, 10, 376-385.

Buschbom, J. \& BARKer, D. 2006. Evolutionary history of vegetative reproduction in Porpidia s.l. (lichen-forming Ascomycota). Systematic Biology, 55, 471-484.

Castello, M. 2003. Lichens of Terra Nova Bay area, northern Victoria Land (continental Antarctica). Studia Geobotanica, 22, 3-54.

Culberson, C.F. \& Johnson, A. 1982. Substitution of methyl tertiary buthyl ether for diethyl ether in the standardized thin-layer chromatographic method for lichen products. Journal of Chromatography, 238, 483-487.

Dodge, C.W. 1973. Lichen flora of Antarctic continent and adjacent islands. Canaan, NH: Phoenix Publishing, 399 pp.

Doran, P.T., Priscu, J.C., Lyons, W.B., Walsch, J.E., Fountain, A.G., McKnight, D.M., Moorhead, D.L., Virginia, R.A., Wall, D.H., Clow, G.D., Fritsen, C.H., McKay, C.P. \& Parsons, A.N. 2002. Antarctic climate cooling and terrestrial ecosystem response. Nature, 415, 517-520.

Dyer, P.S. \& Murtagh, G.J. 2001. Variation in the ribosomal ITSsequence of the lichens Buellia frigida and Xanthoria elegans from the Vestfold Hills, eastern Antarctica. Lichenologist, 33, 151-159.

Filson, R.B. 1974. Studies in Antarctic lichens. II: Lichens from the Windmill Islands, Wilkes Land. Muelleria, 3, 9-36.

Gardes, M. \& BRuns, T.D. 1993. ITS primers with enhanced specifity for basidiomycetes - application to the identification of mycorrhizae and rusts. Molecular Ecology, 2, 113-118.

Green, T.G.A., Schroeter, B. \& Sancho, L.G. 2007. Plant life in Antarctica. In Pugnaire, F.I. \& Valladares, F., eds. Handbook of functional plant ecology, 2nd ed. Boca Raton, FL: CRC Press, 389-433.

Green, T.G.A., Seppelt, R.D. \& Schwarz, A.-M.J. 1992. Epilithic lichens on the floor of the Taylor Valley, Ross Dependency, Antarctica. Lichenologist, 24, 57-61.

Green, T.G.A., Maseyk, K., Pannewitz, S. \& Schroeter, B. 2000. Extreme elevated in situ carbon dioxide levels around the moss Bryum subrotundifolium Jaeg., Ber. S. Gall. in Antarctica. Bibliotheca Lichenologica, 75, 397-403.

Grube, M. \& KroKen, S. 2000. Molecular approaches and the concept of species and species complexes in lichenized fungi. Mycological Research, 104, 1284-1294.

GunN, B.M. \& WalcotT, R.I. 1962. The geology of the Mt. Markham region, Ross Dependency, Antarctica. New Zealand Journal of Geology and Geophysics, 5, 407-426.

GunN, B.M. \& Warren, G. 1962. Geology of Victoria Land between Mawson and Mulock glaciers, Antarctica. New Zealand Geological Survey Bulletin, No. 71, 175 pp.

Hale, M.E. 1987. Epilithic lichens in the Beacon Sandstone Formation, Victoria Land, Antarctica. The Lichenologist, 19, 269-287.

Hawksworth, D.L. \& Rossman, A.Y. 1997. Where are all the undescribed fungi? Phytopathology, 87, 888-891.

Hertel, H. 1987. Progress and problems in taxonomy of Antarctic saxicolous lecideoid lichens. Bibliotheca Lichenologica, 25, 219-242.

Hertel, H. 1988. Problems in monographing in Antarctic crustose lichens. Polarforschung, 58, 65-76.

Hertel, H. 2007. Notes on and records of Southern Hemisphere lecideoid lichens. Bibliotheca Lichenologica, 95, 267-296.

Hertel, H. 2009. A new key to cryptothalline species of the genus Lecidea (Lecanorales). Bibliotheca Lichenologica, 99, 185-204.

HuelsenBeck, J.P. \& Ronquist, F. 2001. MRBAYES: Bayesian inference of phylogenetic trees. Bioinformatics, 17, 754-755.

Inoue, M. 1991. Lecideoid lichens of Prince Olav Coast and Sôya Coast, Enderby Land, East Antarctica. Antarctic Record, 35, 217-284.

Inoue, M. 1995. The lichen flora and habitats of the Syowa region, continental Antarctic. The Lichenologist, 27, 451-462.

Jacobsen, P. \& Kappen, L. 1988. Lichens from the Admiralty Bay region, King Gorge Island (South Shetland Islands, Antarctica). Nova Hedwigia, 46, 503-510. 
Kappen, L., Meyer, M. \& Bölter, M. 1990. Ecological and physiological investigations in continental Antarctic Cryptogams. Flora, 184, 209-220.

Kroken, S. \& TAYLoR, J.W. 2001. A gene genealogical approach to recognize phylogentic species boundaries in the lichenized fungus Letharia. Mycologia, 93, 38-53.

Lee, J.S., Lee, H.K., Hur, J.S., Andreev, M. \& Hong, S.G. 2008. Diversity of the lichenized fungi in King George Island, Antarctica, revealed by phylogenetic analysis of partial large subunit rDNA sequences. Journal of Microbiology and Biotechnology, 18, 1016-1023.

Lücking, R., del Prado, R., Lumbsch, H.T., Will-Wolf, S., Aptroot, A., Sipman, H.J.M., Umaña, L. \& Chaves, J.L. 2008. Phylogenetic patterns of morphological and chemical characters and reproductive mode in the Heterodermia obscurata group in Costa Rica. Systematics and Biodiversity, 6, 31-41.

McGonigal, D. \& Woodworth, L. 2001. Antarctica - the complete story. New Zealand: Global Book Publishing, 608 pp.

MADDISON, D.R. \& MADDISON, W.P. 2003. MacClade 4: analysis of phylogeny and character evolution. Sunderland, MA: Sinauer Associates.

Melick, D.R., Hovenden, M.J. \& Seppelt, R.D. 1994. Phytogeography of bryophyte and lichen vegetation in the Windmill Islands, Wilkes Land, continental Antarctica. Vegetatio, 111, 71-87.

Molina, M.D.C., Crespo, A., Blanco, O., Lumbsch, H.T. \& Hawksworth, D.L. 2004. Phylogenetic relationships and species concepts in Parmelia s. str. (Parmeliaceae) inferred from nuclear ITS rDNA and beta-tubulin sequences. Lichenologist, 36, 37-54.

Nylander, J.A.A., Wilgenbusch, J.C., Warren, D.L. \& Swofford, D.L. 2007. AWTY (Are We There Yet?): a system for graphical exploration of MCMC convergence in Bayesian phylogenetics. Bioinformatics, 24, 581-583.

OhmuRA, Y. \& Kanda, H. 2004. Taxonomic status of section Neuropogon in the genus Usnea elucidated by morphological comparisons and ITS rDNA sequences. Lichenologist, 36, 217-225.

Ott, S., Brinkmann, M., WirTz, N. \& Lumbsch, H.T. 2004. Mitochondrial and nuclear ribosomal DNA data do not support the separation of the Antarctic lichens Umbilicaria kappenii and Umbilicaria antarctica as distinct species. Lichenologist, 36, 227-234.

Øvstedal, D.O. \& Lewis Smith, R.I. 2001. Lichens of Antarctica and South Georgia: a guide to their identification and ecology. Cambridge: Cambridge University Press, $411 \mathrm{pp}$.

Pannewitz, S., Green, T.G.A., Maysek, K., Schlensog, M., Seppelt, R., SANCHO, L.G., TÜRK, R. \& SCHRÖTER, B. 2005. Photosynthetic responses of three common mosses from continental Antarctica. Antarctic Science, 17, 341-352.
Pickard, J. \& Seppelt, R.D. 1984. Phytogeography of Antarctica. Journal of Biogeography, 11, 83-102.

Posada, D. \& Crandall, K.A. 1998. Modeltest: testing the model of DNA substitution. Bioinformatics, 14, 817-818.

Seppelt, R.D., Green, T.G.A. \& Schroeter, B. 1995. Lichens and mosses from the Kar Plateau, southern Victoria Land, Antarctica. New Zealand Journal of Botany, 33, 203-220.

Seppelt, R.D., Nimis, P.L. \& Castello, M. 1998. The genus Sarcogyne (Acarosporaceae) in Antarctica. The Lichenologist, 30, 249-258.

Seppelt, R.D., Broady, P.A., Pickard, J. \& Adamson, D.A. 1988. Plants and landscape in the Vestfold Hills, Antarctica. Hydrobiologia, 165, 185-196.

Seymour, F.A., Crittenden, P.D., Wirtz, N., Ovstedal, D.O., Dyer, P.S. \& LumBsch, H.T. 2007. Phylogenetic and morphological analysis of Antarctic lichen forming Usnea species in the group Neuropogon. Antarctic Science, 19, 71-82.

Simpson, A.L. \& CoOper, A.F. 2002. Geochemistry of the Darwin Glacier region granitoids, southern Victoria Land. Antarctic Science, 14, 425-426.

Sipman, H.J.M. \& AртRoot, A. 2001. Where are the missing lichens? Mycological Research, 105, 1433-1439.

Stocker-Wörgötter, E. \& Elix, J.A. 2002. Secondary chemistry of cultured mycobionts: formations of a complete chemosyndrome by the lichen fungus of Lobaria spathulata. The Lichenologist, 34, 351-359.

Swofford, D.L. 2003. PAUP*. Phylogenetic Analysis Using Parsimony ( ${ }^{*}$ and other methods). Sunderland, MA: Sinauer Associates.

TAYLOR, G. 1913. The western journeys. In HuXley, L., ed. Scott's last expedition. London: Smith Elder, 182-291.

Upreti, D.K. 1996. Lecideoid lichens from the Schirmacher Oasis, East Antarctica. Willdenowia, 25, 681-686.

White, T.J., Bruns, T., Lee, S. \& TAYlor, J. 1990. Amplification and direct sequencing of fungal ribosomal RNA genes for phylogenies. In INNIS, M.A., Gelfand, D.H., Sninsky, J.J. \& White, T.J., eds. PCR protocols: a guide to methods and applications. San Diego, CA: Acadamic Press, 315-322.

Wirtz, N., Printzen, C. \& Lumbsch, H.T. 2008. The delimitation of Antarctic and bipolar species of Usnea, Neuropogon (Ascomycota, Lecanorales): a cohesion approach of species recognition for the Usnea perpusilla complex. Mycological Research, 112, 472-484.

Wirtz, N., Printzen, C., Sancho, L.G. \& Lumbsch, H.T. 2006. The phylogeny and classification of Neuropogon and Usnea (Parmeliaceae, Ascomycota) revisited. Taxon, 55, 367-376.

Zoller, S., Scheidegger, C. \& Sperisen, C. 1999. PCR primers for the amplification of mitochondrial small subunit ribosomal DNA of lichenforming ascomycetes. The Lichenologist, 31, 511-516. 